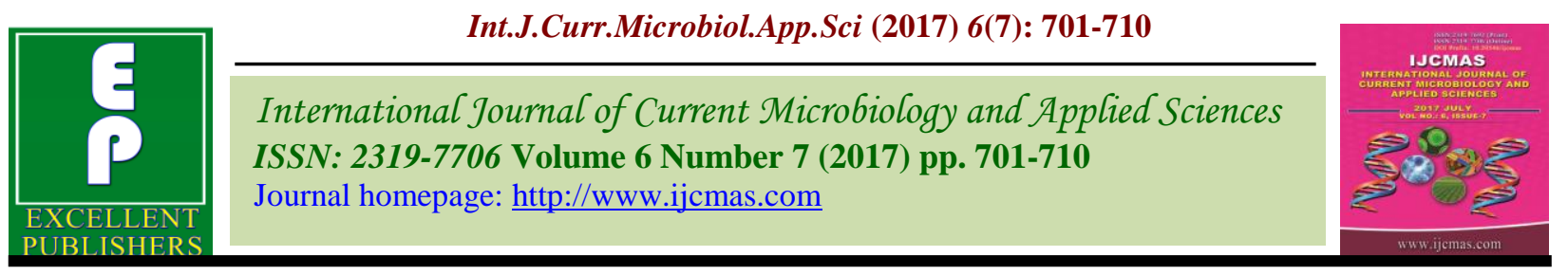

Original Research Article

https://doi.org/10.20546/ijcmas.2017.607.087

\title{
Impact of Sustainable Weed Management Practices on Growth, Phenology and Yield of Rabi Grain Maize (Zea mays L.)
}

\author{
Pradeep Ram ${ }^{1}$, G. Sreenivas ${ }^{2}$ and P. Leela Rani $^{3 *}$ \\ Department of agronomy, College of Agriculture, Professor Jayashankar Telangana State \\ Agricultural University, Rajendranagar, Hyderabad (500 030), India \\ *Corresponding author
}

\begin{tabular}{|c|c|}
\hline & A B S T R A C T \\
\hline & \multirow{4}{*}{ 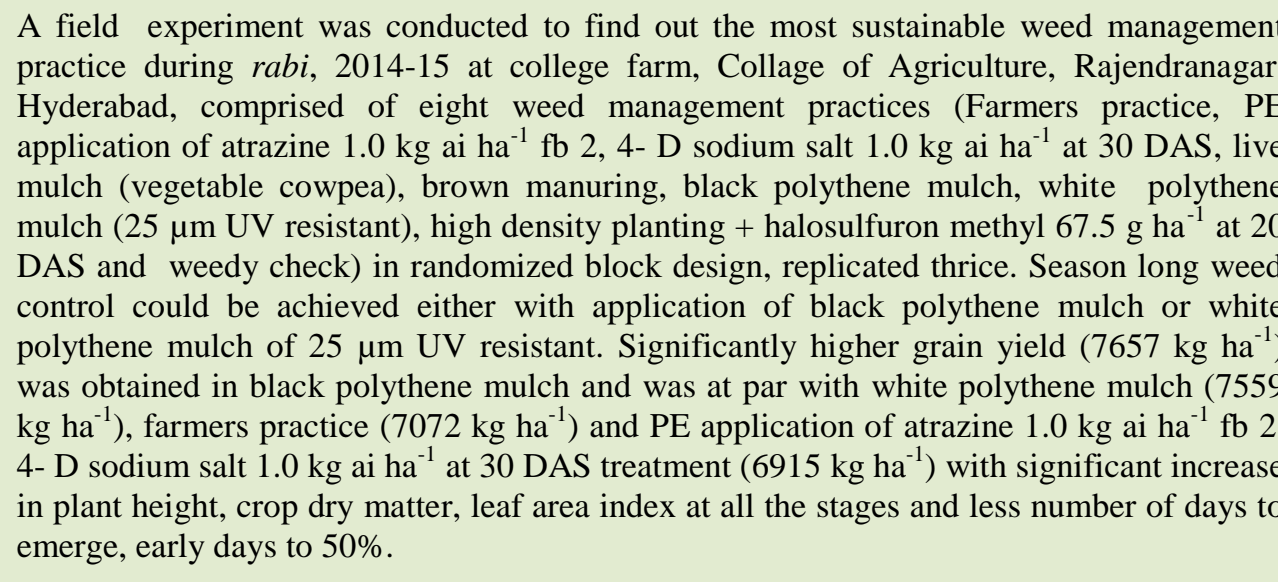 } \\
\hline $\begin{array}{l}\text { Rabi maize, } \\
\text { Growth and } \\
\text { phenology, } \\
\text { Polythene mulch, } \\
\text { Brown manuring, } \\
\text { Live mulch, } \\
\text { Grain yield. }\end{array}$ & \\
\hline Article Info & \\
\hline $\begin{array}{l}\text { Accepted: } \\
\text { 14 June } 2017 \\
\text { Available Online: } \\
\text { 10 July } 2017\end{array}$ & \\
\hline
\end{tabular}

\section{Introduction}

Maize (Zea mays L.) is the world's widely grown highland cereal and primary staple food crop in many developing countries. It is a productive food plant and has highest potential for carbohydrate per unit area per day (Aldrich et al., 1975). Maize ranks third in the cereals world production after rice and wheat, but in productivity it surpasses all cereals. In India, it is grown over an area of $9.43 \mathrm{~m}$ ha with total production of $24.35 \mathrm{~m}$ tones (Anon, 2015). Among the biotic production constraints, weeds are considered as an important category. Worldwide yield losses in maize due to weeds are estimated to be around 37\% (Oerke and Dehne, 2004). In
India, maize, being a rainy season and widely spaced crop, gets infested with variety of weeds and subjected to heavy weed competition, which often inflicts huge losses ranging from 28 to 100 per cent (Patel et al., 2006). Worldwide weed management is primarily focused on curative control, as herbicides are highly effective and relatively cheap (Mortensen et al., 2000; Mohammadi, 2012). Currently, herbicides used to control weeds in maize include pre-emergence application of atrazine, pendimethalin, alachlor and post-emergent application of 2,4D sodium salt. But at the same time, the loss of biodiversity due to environmental 
pollution, high economic costs of herbicides and the increasing selection of herbicide resistant weeds showed reduced sustainability of dominant cropping systems of developed and developing countries. Presently, there are 58 weed species in corn are resistant to herbicides, which is the second highest crop after wheat. Maximum 66 weed species are resistant to herbicide atrazine (Heap, 2014).

In view of this, to minimise the chemical usage and to maintain biodiversity, use of ecological weed management strategies is a typical component of integrated crop management. Low doses of herbicides, use of cover crops, inorganic mulches and high crop density are components of integrated weed management that could be used for effective weed management on smallholder farms. According to Dwivedi et al., (2011) at Raipur, the weed suppression due to smother crop (blackgram + maize intercropping in 1:1) was same as that obtained with two hand weedings at 15 DAS and 30 DAS. In Pakistan at Peshawar, Gul et al., (2009) recorded lower fresh weed biomass in black plastic mulch and was significantly at par with hand weed treatment and lower than that of white plastic mulch, weed mulch and live mulch treatments. At Navasari Gujarat, Arvadiya et $a l$. , (2012) reported significantly lower weed biomass with population density of $1,11,111$ plants ha ${ }^{-1}$ over 83,333 plants ha ${ }^{-1}$.

In addition to above methods, an advanced weed management strategy which has emerged in India is brown manuring. It aimed at suppressing the weeds without affecting the soil physico and chemical properties and its associated microbes. It can be achieved through raising green manure crops such as Sesbania (Daincha), sunhemp etc. as intercrop and killing the same by application of postemergence herbicides. The killed manure is allowed to remain in the field along with main crop without incorporation / in-situ ploughing until its residue decomposes itself in the soil aiming to add organic manure beside weed suppression by its shade effect (Ramachandran et al., 2012).

Atrazine is the second highest consumed (850 tons/annum) selective herbicide in Telangana and Andhra Pradesh states after pretilachlor. Since many herbicides being used in maize viz. atrazine has long residual period in soil affecting environment and next sown crop in rotation. Weeds are controlled by many means. However, in the current scenario of agriculture, evolving eco-friendly approach of weed control is more advisable so as to protect the natural resources such as soil flora and fuana including human being and animals in a holistic manner.

\section{Materials and Methods}

The field experiment was conducted during rabi season of 2014-15 in college farm, College of Agriculture, Rajendranagar, Professor Jayashankar Telangana State Agricultural University, Hyderabad, Telangana State, India, which is geographically situated at an altitude of 542.3 $\mathrm{m}$ above mean sea level at $17^{\circ} 19^{\prime} \mathrm{N}$ latitude and $78^{\circ} 23^{\prime}$ 'E longitude.

The soil of the experimental plot was sandy loam in texture having $\mathrm{pH} 7.45$ and EC 0.50 $\mathrm{dS} \mathrm{m} \mathrm{m}^{-1}$. The soil is having $0.4 \%$ organic carbon, 175.56, 28.84 and $463.41 \mathrm{~kg} \mathrm{ha}{ }^{-1}$ available nitrogen phosphorus and potassium. The experimental treatments comprised of eight weed management practices viz; farmers practice (HW at 20 and 40 DAS), preemergence application of atrazine $1.0 \mathrm{~kg}$ ai $\mathrm{ha}^{-1} \mathrm{fb} 2,4-\mathrm{D}$ sodium salt $1.0 \mathrm{~kg}^{\mathrm{ai} \mathrm{ha}} \mathrm{ha}^{-1}$ at 30 DAS, live mulch (vegetable cowpea), brown manuring (desiccation of cowpea live mulch at $50 \%$ flowering with $2,4-\mathrm{D}$ sodium salt 1 $\mathrm{kg}$ ai $\left.\mathrm{ha}^{-1}\right)$, black polythene mulch $(25 \mu \mathrm{m}$ thickness UV resistant), white polythene 
mulch (25 $\mu \mathrm{m}$ thickness UV resistant), high density planting (planting on either side of the ridge)+halosulfuron methyl $67.5 \mathrm{~g} \mathrm{ha}^{-1}$ at 20 DAS and weedy check (no weed control) were taken for the study.

Grain corn variety Dekalb Super 900M was planted at a seed rate of $12 \mathrm{~kg} \mathrm{ha}^{-1}$ by hand dibbling of two seeds hill ${ }^{-1}$. The crop was sown with spacing of $60 \mathrm{~cm} X 20 \mathrm{~cm}$. After the establishment of the crop, 10 DAS thinning was done by leaving one healthy seedling hill 1 . In experiment, uniform dose of 180-60-40 $\mathrm{kg} \mathrm{N}, \mathrm{P}_{2} \mathrm{O}_{5}, \mathrm{~K}_{2} \mathrm{O}$ ha $^{-1}$ was applied. Entire quantity of $\mathrm{P}_{2} \mathrm{O}_{5}$ and $\mathrm{K}_{2} \mathrm{O}$ and one third of the nitrogen was applied as basal dose at the time of planting. Remaining nitrogen was applied as top dressing at knee high and tasseling stage through spot application. First irrigation was given immediately after sowing of the crop to ensure proper germination. Later irrigations were scheduled uniformly by adopting climatological approach i.e., IW/CPE ratio of 0.8 with $5 \mathrm{~cm}$ depth. Weed count was taken in two randomly selected quadrates $\left(0.5 \times 0.5 \mathrm{~m}^{2}\right)$ in each plot.

The weeds collected from two randomly selected quadrates $(0.5 \mathrm{~m} \times 0.5 \mathrm{~m})$ were used to estimate the dry matter of weeds. The density was recorded at 30,60, 90 DAS and at physiological maturity stage. Data on different characters viz., phenology, growth attributes, weed density and yield were subjected to analysis of variance procedures as outlined for randomized block design (Gomez and Gomez, 1984). In view of the larger variation in the recorded values of density of weeds, the data was subjected to square root transformation $(\sqrt{x+0.5})$ before subjected to statistical analysis as suggested by Gomez and Gomez (1984). Statistical significance was tested by $\mathrm{F}-$ value at 0.05 level of probability and critical difference was worked out where ever the effects were significant.

\section{Results and Discussion}

\section{Weed density and WCE}

During crop growth period total 15 weeds species namely; Parthenium hysterophorus, Melilotus alba, Cyperus rotundus, Trianthema portulacastrum, Dactyloctenium aegyptium, Cynodon dactylon, Digera muricata, Amaranthus viridis, Commelina benghalensis, Eragrostis cilianensis, Chenopodium album, Trichodesma indicum, Digitaria sanguinalis, Euphorbia geneculata and Echinochloa colona were found comprising of broadleaved weeds $49 \%$, grasses $44 \%$ and $7 \%$ sedges.

The mean data depicted in the table 1 during entire crop growth stage showed that all the weed control treatments significantly controlled the weeds compared to weedy check treatment. Significantly reduced weed density was noticed in farmers practice at 30 and 60 DAS and was on par with white polythene mulch and black polythene mulch at 30 DAS, but at 60 DAS and was comparable with high density planting (planting on either side of the ridge)+halosulfuron methyl $67.5 \mathrm{~g} \mathrm{ha}^{-1}$ at 20 DAS tretment, along with black polythene mulch and white polythene mulch treatments. At 90 DAS also high density planting (planting on either side of the ridge)+halosulfuron methyl $67.5 \mathrm{~g} \mathrm{ha}^{-1}$ at 20 DAS tretment showed continued lower weed density and was comparable with black polythene mulch, white polythene mulch, brown manuring and live mulch treatments. The reduced weed density at higher plant population might be attributed to more competitive efficiency of crop at higher plant population (Sarma and Gautam, 2006). But at physiological maturity significant decrease in weed density was noticed in black polythene mulch (5.35) and was at par live mulch (5.47), white polythene mulch (5.55), brown manuring (6.13) and pre- emergence 
application of atrazine $\mathrm{fb} 2,4-\mathrm{D}$ sodium salt at 30 DAS (6.46) treatment. The season long reduced density of weeds in polythene mulch might be due to the sensitivity of the most of the weed seeds to light. So these weed seeds did not germinate under the plastic mulch so ultimately caused a reduction in population (Mahajan et al., 2007). The reduction of weed infestation with application of herbicide can be attributed to the phytotoxic effect of herbicides on weeds and led to inhibition of seed germination and photosynthesis in weeds (Mahadi, 2014).

Weed control efficiency is used to compare the efficiency of the applied herbicide or herbicidal treatments (Table 2). Similar trend was observed as weed density. At 30 DAS and 60 DAS maximum weed control efficiency $(83.88 \%)$ was noticed in farmers practice and was followed by black polythene mulch, white polythene mulch and high density planting. This might be due to suppressive effect of manual weeding and smothering effect of high density planting during early stages of the crop growth. At physiological maturity also higher weed control efficiency recorded in black polythene mulch, in turn this was followed by live mulch, white polythene mulch, brown manuring. The sustainable weed management practices like application of organic, inorganic and live mulches late in the season also provide season long weed control efficiency through reduced density of weeds. The reduced weed control efficiency of farmer practice and pre-emergence application of atrazine fb 2, 4- D sodium salt at 30 DAS treatments was due to the reduced efficacy of applied herbicide and manual weeding after 40 DAS, resulted in increased density of weeds during later stages of the crop growth.

\section{Phenology}

The effect of different weed management practices on days to emergence and phenology of rabi grain maize is depicted in table 3. Sustainable weed management practices along with regular chemical and cultural practices significantly improve the days to emergence and phenology. Statistical analysis of the data indicated that, application of either black or white polythene mulch fastened the emergence of maize crop by 2 days earlier than other treatments tried under study. The early emergence might be due to increase in soil temperature under the plastic mulch. Similarly, Liu et al., (2014) recorded increased soil temperature by 1.0 to $1.5^{\circ} \mathrm{C}$ due to film mulching during the maize early growth season and thus seedlings emerged 3 to 4 days earlier than that of non mulched plots.

Minimum number of days (70 days) to attain $50 \%$ tasseling was observed with black polythene mulch and white polythene mulch and was at par with farmers practice and preemergence application of atrazine $1.0 \mathrm{~kg}$ ai $\mathrm{ha}^{-1} \mathrm{fb} 2,4-\mathrm{D}$ sodium salt $1.0 \mathrm{~kg}^{\mathrm{ai} \mathrm{ha}} \mathrm{ha}^{-1}$ at 30 DAS and were taken significantly less number of days over all other weed management practices. However, these were followed by high density planting + halosulfuron methyl $67.5 \mathrm{~g} \mathrm{ha}^{-1}$ at $20 \mathrm{DAS}$, live mulch, brown manuring and weedy check treatments with $75,85,85$ and 85 days respectively. These results are similar to Liu et al., (2014), who reported earlier silking in maize plants by 7 to 18 days and had a longer reproductive stage than those non mulched treatments. The promotion of transpiration with little soil evaporation might have fostered biomass accumulation during early growth stages and accelerated plant growth.

\section{Plant height}

Perusal of data on plant hight at different stages (Table 4) showed that, application of black polythene mulch increased the plant hight significantly and was comparable with white polythene mulch at 30 DAS. But at 60, 
90 DAS and at physiological maturity stage more plant height was noticed in farmers practice. This was comparable with black polythene mulch, white polythene mulch and pre emergence application of atrazine $1.0 \mathrm{~kg}$ ai ha ${ }^{-1} \mathrm{fb} 2$, 4- D Sodium salt $1.0 \mathrm{~kg}$ ai ha ${ }^{-1}$ at 30 DAS. The increased plant height in polythene mulch was attributed to excellent weed control, high water use efficiency along with early and vigorous growth of plants (Mahajan et al., 2007).

\section{Crop drymatter}

The mean data presented in table 5 on crop drymatter at diiferent growth stages revealed that, black polythene mulch recorded significantly higher crop drymatter at all the growth stages. However this was comparable with white polythene mulch and farmers practice at $60 \mathrm{DAS}$, white polythene mulch at 90 DAS. However at physiological maturity stage and was at par with white polythene mulch, farmers practice and pre-emergence application of atrazine $1 \mathrm{~kg}^{\text {ai }} \mathrm{ha}^{-1} \mathrm{fb} \mathrm{2,4-D}$ sodium salt $1.0 \mathrm{~kg}$ ai $\mathrm{ha}^{-1}$. The increased drymatter in polythene mulch at all the stages might be due to reflection of PAR into plant canopy, increased photosynthesis and biomass accumulation. The increased growth and yield observed in plastic film mulched plots could be attributed to its ability to increase soil temperature, water retention, soil porosity and decrease soil bulk density (Loy et al., 1998). Herbicides minimised competition for growth resources between crops and weeds which led to greater efficiency in utilizing growth and yield resources by the crops (Mahadi, 2014).

\section{Leaf area index}

Gradual increase in LAI was observed from 30 DAS up to 90 DAS and thereby decreasing trend was observed at physiological maturity (Table 6). At all the growth stages significantly higher LAI was recorded in high density planting+halosulfuron methyl $67.5 \mathrm{~g}$ $\mathrm{ha}^{-1}$ at 20 DAS treatment, inturn this was at par with white polythene mulch at 30 DAS, thereafter this was followed by black polythene mulch at 60 DAS, 90 DAS and at physiological maturity stages. Higher LAI in high density planting might be due to more number of plants per unit area attributing more leaf area per unit land area with slight reduction in leaf area per plant. While, the higher leaf area index in the polythene mulch and hand weeding might be attributed to their weed control, thus providing favorable conditions also accelerated vegetative growth in polythene mulches (Gul et al., 2009).

\section{Grain yield}

Higher grain yield $\left(7657 \mathrm{~kg} \mathrm{ha}^{-1}\right)$ was obtained in black polythene mulch and was at par with white polythene mulch, farmers practice and pre-emergence application of atrazine $1 \mathrm{~kg}$ ai $\mathrm{ha}^{-1} \mathrm{fb} 2,4-\mathrm{D}$ sodium salt $1.0 \mathrm{~kg}^{\mathrm{ai} \mathrm{ha}} \mathrm{ha}^{-1}$ at 30 DAS. The lowest yield was obtained in weedy check treatment (Table 3). The increased grain yield in polythene mulch may be due to rise in soil temperature, thereby promoting faster crop development (Ndubuisi, 2009). According to Tollenaar and Lee (2006) increase in maize grain yield under polythene mulches was mainly attributed to an increase in biomass production, especially during the reproductive stage. Higher grain yield under two hand weedings might be due to effective control of weeds during critical period of crop growth, which promote competition free growth of maize. While, increased grain yield with herbicide was because the herbicides prevented the germination of weed and reduced the growth of weed (Samant et al., 2015). Although grain yield in live mulch treatment was significantly lower than polythene mulch treatments but higher than weedy check treatment. 
Table.1 Effect of weed management practices on total weed density (no. m-2) of rabi maize

\begin{tabular}{|c|c|c|c|c|}
\hline Treatments & $30 \mathrm{DAS}$ & 60 DAS & 90 DAS & Maturity \\
\hline Farmers practice (HW at $20 \& 40 \mathrm{DAS})$ & $\begin{array}{c}8.58 \\
(72.67)\end{array}$ & $\begin{array}{c}7.57 \\
(56.67)\end{array}$ & $\begin{array}{c}8.93 \\
(79.33)\end{array}$ & $\begin{array}{c}6.70 \\
(44.00)\end{array}$ \\
\hline $\begin{array}{l}\text { Pre- emergence application of atrazine @ } 1 \mathrm{~kg} \mathrm{a}^{-i} \mathrm{ha}^{-1} \mathrm{fb} 2,4-\mathrm{D} \\
\text { sodium salt @ } 1.0 \mathrm{~kg} \mathrm{a}^{-1} \mathrm{ha}^{-1} \text { at } 30 \mathrm{DAS}\end{array}$ & $\begin{array}{c}12.56 \\
(160.67)\end{array}$ & $\begin{array}{c}10.15 \\
(103.33)\end{array}$ & $\begin{array}{c}9.17 \\
(83.33)\end{array}$ & $\begin{array}{c}6.46 \\
(42.00)\end{array}$ \\
\hline Live mulch (vegetable cowpea) & $\begin{array}{c}21.04 \\
(442.00)\end{array}$ & $\begin{array}{c}11.65 \\
(136.00)\end{array}$ & $\begin{array}{c}7.13 \\
(51.33)\end{array}$ & $\begin{array}{c}5.47 \\
(29.00)\end{array}$ \\
\hline $\begin{array}{l}\text { Brown manuring (Desiccation of cowpea live mulch at } 50 \% \\
\text { flowering with 2, 4-D sodium salt @ } 1 \mathrm{~kg} \mathrm{a}^{-1} \mathrm{ha}^{-1} \text { ) }\end{array}$ & $\begin{array}{c}20.24 \\
(411.33) \\
\end{array}$ & $\begin{array}{c}12.03 \\
(145.33)\end{array}$ & $\begin{array}{c}6.92 \\
(48.00)\end{array}$ & $\begin{array}{c}6.13 \\
(36.67)\end{array}$ \\
\hline Black polythene mulch ( $25 \mu \mathrm{m}$ thickness UV resistant $)$ & $\begin{array}{c}8.66 \\
(74.67) \\
\end{array}$ & $\begin{array}{c}8.36 \\
(70.00) \\
\end{array}$ & $\begin{array}{c}6.89 \\
(46.67) \\
\end{array}$ & $\begin{array}{c}5.35 \\
(27.67) \\
\end{array}$ \\
\hline White polythene mulch ( $25 \mu \mathrm{m}$ thickness UV resistant $)$ & $\begin{array}{c}8.82 \\
(78.00)\end{array}$ & $\begin{array}{c}8.58 \\
(74.67)\end{array}$ & $\begin{array}{c}7.22 \\
(51.33)\end{array}$ & $\begin{array}{c}5.55 \\
(30.00)\end{array}$ \\
\hline $\begin{array}{l}\text { High density planting (planting on either side of the ridge) }+ \\
\text { halosulfuron methyl @ } 67.5 \mathrm{~g} \mathrm{ha}^{-1} \text { at } 20 \text { DAS }\end{array}$ & $\begin{array}{c}11.33 \\
(128.00)\end{array}$ & $\begin{array}{c}7.58 \\
(57.33)\end{array}$ & $\begin{array}{c}6.70 \\
(44.00) \\
\end{array}$ & $\begin{array}{c}6.70 \\
(44.00) \\
\end{array}$ \\
\hline Weedy check (no weed control) & $\begin{array}{c}21.16 \\
(450.67)\end{array}$ & $\begin{array}{c}14.55 \\
(213.33)\end{array}$ & $\begin{array}{c}9.27 \\
(85.00)\end{array}$ & $\begin{array}{c}7.08 \\
(49.33)\end{array}$ \\
\hline S.Em \pm & 0.61 & 0.79 & 0.51 & 0.37 \\
\hline C.D $(p=0.05)$ & 1.88 & 2.41 & 1.55 & 1.13 \\
\hline C.V $(\%)$ & 7.56 & 13.58 & 11.30 & 10.31 \\
\hline
\end{tabular}

Note: Figure in parenthesis are original values

Table.2 Effect of weed management practices on weed control efficiency of rabi maize

\begin{tabular}{|c|c|c|c|c|}
\hline Treatments & $30 \mathrm{DAS}$ & 60 DAS & 90 DAS & Maturity \\
\hline Farmers practice (HW at $20 \& 40 \mathrm{DAS})$ & 83.88 & 73.44 & 6.67 & 10.80 \\
\hline $\begin{array}{l}\text { Pre- emergence application of atrazine @ } 1 \mathrm{~kg} \mathrm{a}^{-i} \mathrm{ha}^{-1} \mathrm{fb} 2,4-\mathrm{D} \\
\text { sodium salt @ } 1.0 \mathrm{~kg} \mathrm{a}^{-1} \mathrm{ha}^{-1} \text { at } 30 \mathrm{DAS}\end{array}$ & 64.35 & 51.56 & 1.96 & 14.86 \\
\hline Live mulch (vegetable cowpea) & 1.92 & 36.25 & 39.61 & 41.21 \\
\hline $\begin{array}{l}\text { Brown manuring (Desiccation of cowpea live mulch at } 50 \% \\
\text { flowering with 2, 4-D sodium salt @ } 1 \mathrm{~kg} \mathrm{a.i} \mathrm{ha}^{-1} \text { ) }\end{array}$ & 8.73 & 31.88 & 43.53 & 25.66 \\
\hline Black polythene mulch ( $25 \mu \mathrm{m}$ thickness UV resistant) & 83.43 & 67.19 & 45.09 & 43.91 \\
\hline White polythene mulch ( $25 \mu \mathrm{m}$ thickness UV resistant) & 82.69 & 65.00 & 39.61 & 39.19 \\
\hline $\begin{array}{l}\text { High density planting (planting on either side of the ridge) + } \\
\text { halosulfuron methyl @ } 67.5 \mathrm{~g} \mathrm{ha}^{-1} \text { at } 20 \mathrm{DAS}\end{array}$ & 71.60 & 73.13 & 48.24 & 10.80 \\
\hline Weedy check (no weed control) & 0.00 & 0.00 & 0.00 & 0.00 \\
\hline
\end{tabular}


Table.3 Effect of weed management practices on days to emergence, days to $50 \%$ tasseling and grain yield of rabi maize

\begin{tabular}{|l|c|c|c|}
\hline Treatments & $\begin{array}{c}\text { Days to } \\
\text { emergence }\end{array}$ & $\begin{array}{c}\text { Days to 50\% } \\
\text { tasseling }\end{array}$ & $\begin{array}{c}\text { Grain yield } \\
\left.\text { (kg ha }^{-1}\right)\end{array}$ \\
\hline Farmers practice (HW at 20 \&40 DAS) & 7 & 72 & 7072 \\
\hline $\begin{array}{l}\text { Pre- emergence application of atrazine @ 1 kg a.i ha }{ }^{-1} \mathrm{fb} 2,4-\mathrm{D} \\
\text { sodium salt @ 1.0 kg a.i ha }{ }^{-1} \text { at 30 DAS }\end{array}$ & 7 & 72 & 6915 \\
\hline Live mulch (vegetable cowpea) & 7 & 85 & 4263 \\
\hline $\begin{array}{l}\text { Brown manuring (Desiccation of cowpea live mulch at 50\% } \\
\left.\text { flowering with 2, 4-D sodium salt @ 1 kg a.i ha }{ }^{-1}\right)\end{array}$ & 7 & 85 & 3860 \\
\hline Black polythene mulch (25 $\mu \mathrm{m}$ thickness UV resistant) & 5 & 70 & 7657 \\
\hline White polythene mulch $(25 \mu \mathrm{m}$ thickness UV resistant) & 5 & 70 & 7559 \\
\hline $\begin{array}{l}\text { High density planting (planting on either side of the ridge) + } \\
\text { halosulfuron methyl @ } 67.5 \mathrm{~g} \text { ha }{ }^{-1} \text { at 20 DAS }\end{array}$ & 7 & 75 & 5337 \\
\hline Weedy check (no weed control) & 7 & 85 & 3,850 \\
\hline S.Em \pm & 0.47 & 3.01 & 252.97 \\
\hline C.D (p=0.05) & 1.44 & 9.23 & 774.73 \\
\hline C.V (\%) & 12.51 & 6.80 & 7.54 \\
\hline
\end{tabular}

Table.4 Effect of weed management practices on plant height $(\mathrm{cm})$ of rabi maize

\begin{tabular}{|c|c|c|c|c|}
\hline Treatments & 30 DAS & 60 DAS & 90 DAS & maturity \\
\hline Farmers practice (HW at $20 \& 40 \mathrm{DAS}$ ) & 17 & 119 & 190 & 185 \\
\hline $\begin{array}{l}\text { Pre- emergence application of atrazine @ } 1 \mathrm{~kg} \mathrm{a}^{-i} \mathrm{ha}^{-1} \mathrm{fb} 2,4-\mathrm{D} \\
\text { sodium salt @ } 1.0 \mathrm{~kg} \mathrm{a.i} \mathrm{ha}{ }^{-1} \text { at } 30 \text { DAS }\end{array}$ & 18 & 100 & 178 & 174 \\
\hline Live mulch (vegetable cowpea) & 17 & 76 & 172 & 163 \\
\hline $\begin{array}{l}\text { Brown manuring (Desiccation of cowpea live mulch at } 50 \% \\
\text { flowering with } 2,4-D \text { sodium salt @ } 1 \mathrm{~kg} \mathrm{a}^{-i} \mathrm{ha}^{-1} \text { ) }\end{array}$ & 16 & 73 & 160 & 161 \\
\hline Black polythene mulch $(25 \mu \mathrm{m}$ thickness UV resistant $)$ & 22 & 115 & 186 & 184 \\
\hline White polythene mulch $(25 \mu \mathrm{m}$ thickness UV resistant $)$ & 21 & 116 & 185 & 182 \\
\hline $\begin{array}{l}\text { High density planting (planting on either side of the ridge) }+ \\
\text { halosulfuron methyl @ } 67.5 \mathrm{~g} \mathrm{ha}^{-1} \text { at } 20 \mathrm{DAS}\end{array}$ & 17 & 96 & 174 & 167 \\
\hline Weedy check (no weed control) & 17 & 84 & 163 & 160 \\
\hline S.Em \pm & 2.94 & 19.95 & 14.10 & 11.92 \\
\hline C.D $(\mathrm{p}=0.05)$ & 0.96 & 6.51 & 4.60 & 3.89 \\
\hline C.V (\%) & 9.16 & 11.59 & 4.53 & 3.92 \\
\hline
\end{tabular}


Table.5 Effect of weed management practices on crop drymatter (g plant-1) of rabi maize

\begin{tabular}{|l|c|c|c|c|}
\hline Treatments & 30 DAS & 60 DAS & 90 DAS & Maturity \\
\hline Farmers practice (HW at 20 \&40 DAS) & 3 & 106 & 183 & 451 \\
\hline $\begin{array}{l}\text { Pre- emergence application of atrazine @ 1 kg a.i ha }{ }^{-1} \mathrm{fb} 2,4-\mathrm{D} \\
\text { sodium salt @ 1.0 kg a.i ha }{ }^{-1} \text { at 30 DAS }\end{array}$ & 4 & 98 & 168 & 445 \\
\hline Live mulch (vegetable cowpea) & 2 & 43 & 109 & 250 \\
\hline $\begin{array}{l}\text { Brown manuring (Desiccation of cowpea live mulch at 50\% } \\
\text { flowering with 2, 4-D sodium salt @ 1 kg a.i ha }{ }^{-1}\end{array}$ & 2 & 35 & 142 & 327 \\
\hline Black polythene mulch $(25 \mu \mathrm{m}$ thickness UV resistant) & 5 & 124 & 238 & 489 \\
\hline White polythene mulch $(25 \mu \mathrm{m}$ thickness UV resistant) & 4 & 116 & 204 & 466 \\
\hline $\begin{array}{l}\text { High density planting (planting on either side of the ridge) } \\
\text { halosulfuron methyl @ 67.5 g ha }{ }^{-1} \text { at 20 DAS }\end{array}$ & 3 & 55 & 127 & 271 \\
\hline Weedy check (no weed control) & 2 & 52 & 104 & 232 \\
\hline S.Em \pm & 0.24 & 6.14 & 12.23 & 20.84 \\
\hline C.D (p=0.05) & 0.74 & 18.79 & 37.46 & 45.13 \\
\hline C.V (\%) & 13.63 & 13.54 & 13.30 & 6.97 \\
\hline
\end{tabular}

Table.6 Effect of weed management practices on leaf area index of rabi maize

\begin{tabular}{|c|c|c|c|c|}
\hline Treatments & 30 DAS & 60 DAS & 90 DAS & Maturity \\
\hline Farmers practice (HW at $20 \& 40 \mathrm{DAS})$ & 0.79 & 2.23 & 3.66 & 1.82 \\
\hline $\begin{array}{l}\text { Pre- emergence application of atrazine @ } 1 \mathrm{~kg} \mathrm{a} . \mathrm{i} \mathrm{ha}^{-1} \mathrm{fb} 2,4-\mathrm{D} \\
\text { sodium salt @ } 1.0 \mathrm{~kg} \mathrm{a.i} \mathrm{ha}{ }^{-1} \text { at } 30 \text { DAS }\end{array}$ & 0.77 & 2.16 & 3.43 & 1.40 \\
\hline Live mulch (vegetable cowpea) & 0.39 & 1.87 & 3.15 & 1.38 \\
\hline $\begin{array}{l}\text { Brown manuring (Desiccation of cowpea live mulch at } 50 \% \\
\text { flowering with 2, 4-D sodium salt @ } 1 \mathrm{~kg} \mathrm{a}^{-1} \mathrm{ha}^{-1} \text { ) }\end{array}$ & 0.37 & 1.72 & 3.12 & 1.35 \\
\hline Black polythene mulch ( $25 \mu \mathrm{m}$ thickness UV resistant) & 1.00 & 2.45 & 3.82 & 1.89 \\
\hline White polythene mulch ( $25 \mu \mathrm{m}$ thickness UV resistant $)$ & 1.03 & 2.25 & 3.70 & 1.84 \\
\hline $\begin{array}{l}\text { High density planting (planting on either side of the ridge) + } \\
\text { halosulfuron methyl @ } 67.5 \mathrm{~g} \mathrm{ha}^{-1} \text { at } 20 \mathrm{DAS}\end{array}$ & 1.09 & 4.40 & 5.49 & 2.35 \\
\hline Weedy check (no weed control) & 0.45 & 1.67 & 2.95 & 1.30 \\
\hline S.Em \pm & 0.03 & 0.18 & 0.16 & 0.09 \\
\hline C.D $(p=0.05)$ & 0.08 & 0.56 & 0.49 & 0.28 \\
\hline C.V (\%) & 6.13 & 13.52 & 7.61 & 9.36 \\
\hline
\end{tabular}


This might be the result of competition between crop, live mulch and weed on environmental parameters such as light, water and space which reduces photosynthesis and production (Moosavi et al., 2012). The reduced grain yield of maize with increasing weed densities in different treatments was the result of the observed decrease in number of grains $\mathrm{cob}^{-1}$, grain weight $\mathrm{cob}^{-1}$ and 100 -grain weight due to increased severity in competition and allelopathic interference by weeds (Safdar et al., 2015). Low grain yield of maize in weedy check might be due to vigorous weed growth and suppression in crop growth (Samant et al., 2015).

Based on experimental results this experiment was concluded that, application of either black or white polythene mulch of $25 \mu \mathrm{m}$ thickness UV resistant or farmers practice ie hand weeding twice at 20 and 40 DAS or preemergence application of atrazine $1.0 \mathrm{~kg}$ ai $\mathrm{ha}^{-1} \mathrm{fb} 2,4-\mathrm{D}$ sodium salt $1.0 \mathrm{~kg}^{\mathrm{ai} \mathrm{ha}} \mathrm{ha}^{-1}$ at 30 DAS effectively controlled weeds and increased the grain yield of rabi maize with improved growth attributes. With view of lack of labourer for manual weeding and impact of herbicide on environment application of polythene mulches in weed management can prove a key for sustainable development of agriculture to meet the food needs of present fastening population.

\section{References}

Aldrich, S.R., W.O. Scott. and Leng, E.R., 1975. Modern Crop Production. (2nd Edn.). A \& L Publication, Champaign, IL, USA.

Anonymous. 2015. Area, production and yield of cotton in India (major states). Technical Report, Directorate of Economics and Statistics, Department of Agriculture and Cooperation, New Delhi, p. 90.

Arvadiya, L.K., V.C. Raj,, T.U. Patel,, M.K.
Arvadia and Patel, A.M. 2012. Effect of plant population and weed management practices on productivity of sweet corn. Indian J Weed Sci. 44(3): 167-171.

Dwivedi, S.K., G.K. Shrivastava,, A.P. Singh and Kolhe, S.S. 2011. Weed population, nitrogen removal by weeds and crop yield under maize+blackgram intercropping system in Chhattisgarh plains. Indian J. Weed Sci., 43 (3\&4): 203-210.

Food and Agricultural Organization Statistics. Available from http://faostat.fao.org/ site/339/ default.aspx.

Gomez, K.A. and Gomez, A.A. 1984. Statistical procedures for agriculture research. John Wiley and Sons Publishers, New York, 357-423.

Gul, B., M.B. Marwat, G. Hassan, A. Khan,, S. Hashim and Khan, I.A. 2009. Impact of tillage, plant population and mulches on biological yield of maize. Pak. J. Bot., 41(5): 2243-2249.

Heap, I. 2014. The International Survey of Herbicide Resistant Weeds. http://www.weedscience.org/in.asp

Liu, J., L. Bu., L. Zhu., S. Luo., X. Chen and Li, S. 2014. Optimizing plant density and plastic film mulch to increase maize productivity and water-use efficiency in semiarid areas. Agron J., 106: 11381146.

Loy, J.B., O.S. Wells., S.M. Karakodas and Milbert, K. 1998. Comparative effects of red and black polyethylene mulch on growth, assimilate partitioning and yield in trellised tomato. Proceedings of National Agricultural Plastic Congress, 27: $188-197$

Mahadi, M.A. 2014. Growth, nutrient uptake and yield of maize (Zea mays L.) as influenced by weed control and poultry manure, Int. J. Sci. Nat., 5(1): 94-102.

Mahajan, G.R. Sharda., A. Kumar and Singh, K.G. 2007. Effect of plastic mulch on economizing irrigation water and weed 
control in baby corn sown by different methods. Afr. J. Agric. Res., 2 (1): 019026.

Mohammadi, G.R. 2012. Living mulch as a tool to control weeds in agroecosystems: A Review. In: Price, A.J. (Ed.), Weed Control. In Tech Press, Croatia, pp. 75-100.

Moosavi, S.G., M.J. Seghatoleslami and Moazeni, A. 2012. Effect of planting date and plant density on morphological traits, LAI and forage corn (Sc. 370) yield in second cultivation. Int. Res. J. Appl. Basic Sci., 3(1): 57-63.

Mortensen, D.A., L. Bastiaans and Sattin, M. 2000. The role of ecology in the development of weed management systems: An outlook. Weed Res., 40: 49-62.

Ndubuisi, M.C. 2009. Physical properties of an ultisol under plastic film and nomulches and their effect on the yield of maize. J. Am. Sci., 5(5): 25-30.

Oerke, E.C. and Dehne, H.W. 2004. Safeguarding production losses in major crops and the role of crop protection. Crop Prot., 23: 275-85.

Patel, V.J., P.N. Upadhyay., J.B. Patel and Meisuriya, M.I. 2006. Effect of Herbicide mixtures on weeds in kharif maize (Zea Mays L.) under Middle Gujarat conditions. Indian J. Weed Sci., 38 (1\&2): 54-57.

Ramachandran, A., A. Veeramani and Prema, P. 2012. Effect of brown manuring on weed growth, yield and economics of irrigated maize. Indian J. Weed Sci., 44(3): 204-206.

Safdar, M.E., A.Tanveer., A. Khaliq and Riaz, M.A. 2015. Yield losses in maize (Zea mays) infested with parthenium weed (Parthenium hysterophorus L.). Crop Prot., 70: 77-82.

Samant, T.K., B.C. Dhir and Mohanty, B. 2015. Weed growth, yield components, productivity, economics and nutrient uptake of maize (Zea mays L.) as influenced by various herbicide applications under rainfed condition. Scholars J. Agri. Vet., 2(1B): 79-83.

Sarma, C.K and Gautam, R.C. 2006. Effect of Tillage, Seed Rate and Weed Control Methods on Weeds and Maize (Zea mays L.). Indian J. Weed Sci., 38(1\&2): 58-61.

Tollenaar, M. and Lee, E.A. 2006. Dissection of physiological processes underlying grain yield in maize by examining genetic improvement and heterosis. Maydica, 51: 399-408.

\section{How to cite this article:}

Pradeep Ram, G. Sreenivas and P. Leela Rani. 2017. Impact of Sustainable Weed Management Practices on Growth, Phenology and Yield of Rabi Grain Maize (Zea mays L.).

Int.J.Curr.Microbiol.App.Sci. 6(7): 701-710. doi: https://doi.org/10.20546/ijcmas.2017.607.087 